\title{
Selected Reference Books of 1954-1955
}

Miss Winchell is reference librarian, Columbia University.

\section{INTRODUCTION}

$\mathrm{L}$ IKE THE PRECEDING ARTICLES in this semiannual series ${ }^{1}$ this survey is based on notes written by members of the reference staff of the Columbia University libraries. Notes written by assistants are signed with initials. ${ }^{2}$

As the purpose of the list is to present a selection of recent scholarly and foreign works of interest to reference workers in university libraries, it does not pretend to be either well-balanced or comprehensive. Code numbers (such as A1l and 1A26) have been used to refer to titles in the Guides and its first Supplement.

\section{BIBLIOGRAPHY}

Besterman, Theodore. A World Bibliography of Bibliographies... 3d. rev. ed. Genève, Societas Bibliographica [1955- ] v. 1- . 90 Sw.fr.

Contents: v. 1, A-E. 1326 col.

The author estimates that this edition, to comprise four volumes, will list 80,000 separate items, compared with 65,000 included in the preceding edition (Guide A11). Examination of the first volume substantiates this figure, with new materials particularly noticeable under such topical headings as "Aeronautics," "Atom, Atomic energy," etc. Coverage through the closing date of 1953 seems adequately met, with a few later entries included as they became available. Arrangement, scope and limitations remain as

1 COLLEGE AND RESEARCH LIBRARIES, January and July issues, starting January 1952 .

Eleanor Buist, Kenneth Lohf, Suzanne Szasz, Eugene Sheehy, John Neal Waddell.

3 Constance M. Winchell, Guide to Reference Books (7th ed.; Chicago: ALA, 1951) ; Supplement (Chicago: ALA, 1954). in the earlier editions, so that only upon appearance of the author-index volume can full use of the set be made. For the first time, the author has worked extensively with the resources of the Library of Congress, and to seemingly good effect for inclusion of U.S. items. Even so, the number of bibliographic inconsistencies and omissions in American imprints is abnormally high.-J.N.W.

\section{Bibliographie der Übersetzungen} deutschsprachiger Werke. Verzeichnis der Seit 1951 erschienenen und in der Deutschen Bücherei vorhandenen Schriften, bearb. und hrsg. von der Deutschen Bücherei. Leipzig, VEB Verlag für Buch- und Bibliothekswesen, 1954- . Jg. 1- . quarterly.

A quarterly bibliography listing translations from the German into other languages, which have been published since 1951. The arrangement is by large class groups, subdivided by languages with an author index. Bibliographical information is detailed, the translated title is followed by the original German title in brackets, and prices are included. It is hoped that a volume covering 1945-1950 will follow.

Evans, Charles. The American Bibliography ... v. 13, 1799-1800, by Clifford K. Shipton. Worcester, Mass., American Antiquarian Society, 1955. 349 p. $\$ 25$.

A carefully edited continuation of an invaluable bibliography (Guide A142). Volume 13 completes the year 1799, which had only been covered through the letter " $M$ " in volume 12, and brings the work down through the end of 1800 , with author and subject indexes. Most of the items included were either examined or verified in reliable bibliographies, and not, as so often occurs 
in Evans' work, accepted on the basis of booksellers' advertisements. Those titles not examined or described by a careful bibliographer have been put in brackets. When an anonymous work is listed under author, cross-reference is given from the title. Imprint information is given more fully than in previous volumes, but, because of considerations of space and cost, titles have been abbreviated to include only their essential portions. Nearly all of the items have been located in libraries or private collections, and, in most cases, multiple locations have been listed. It is heartening to read in the introduction that negotiations are now underway regarding the preparation of a final volume which would include a supplement and index to the complete set.-K.L.

Paperbound Books in Print. New York, Bowker, 1955- . \$2. per year.

Intended as "an easy-to-use index to available paper books," the work is scheduled to appear three times a year (January, April, and September) and will include both items in print and those announced for publication within the next quarter. The first part is a selective subject index with alphabetical title arrangement under broad subject headings, plus a highly selective fiction index containing a mere sampling of titles. The principal part of the work is an author listing with more than 4500 items appearing in the Summer number. Price, publication number, and publisher's symbol are included in each entry.--E.S.

Pennink, R. Catalogus der Niet-Nederlandse drukken:1500-1540 aanwezig in de Koninklijke Bibliotheek 's-Gravenhage. 's-Gravenhage, Staatsdrukkerij- en Uitgeverijbedrijf, 1955. 267p. G.20.

May be ordered from Nijhoff. 2373 numbered entries.

Lists European imprints, 1500-1540, not published in the Netherlands, which are in the national library. Detailed references are given to bibliographic sources and there are indexes by printers and original owners.
Taube, Gurli Elisa. Svensk festskriftsbibliografiâren 1891-1925. Uppsala, Appelbergs Boktryckeri, 1954. 168p. (Svenska bibliotekariesamfundets skriftserie, II)

A listing of Swedish festschriften arranged alphabetically by person honored, giving the full contents of each volume. There is a classed index by subject field and an author index to the contents of the volumes.

\section{U.S. Library of Congress. General Ref-} erence and Bibliography Division. Current National Bibliographies, compiled by Helen F. Conover. Washington, D. C., Government Printing Office, 1955 . 132p. $\$ .75$.

An extension of the series, "Current National Bibliographies," printed from 1949 to 1953 in the Library of Congress Quarterly Journal of Current Acquisitions (Guide A132 and 1A26). Limited to sources being published currently in mid-1954, the bibliography includes lists of publications of all kinds-books, documents, pamphlets, serials, theses, maps, music. However, specialized and selective subject lists of general literature are included only for countries where fuller sources are not available. With few exceptions, all of the items are being received currently by the Library of Congress.

Arrangement is by broad political areas and individual countries. Where resources for a particular country are extensive, items are grouped under the following headings: general (mainly books), indexes of periodical articles, government documents, and directories of periodicals and newspapers. Bibliographical description is complete, and nearly all of the entries are annotated. There is an index of titles and a directory of publishers.-K.L.

\section{ENCYCLOPEDIAS}

Ensiklopedia Indonesia. Bandung, N. V. Penerbitan; 's-Gravenhage, W. Van Hoeve, 1954- . v.1- . il. $\$ 8.50$ per vol. v.1, A-E.

Characterized by very brief articles on a 
wide variety of subjects (including biographies of living persons) this general encyclopedia emphasizes Asiatic affairs. Unfortunately, no bibliographies are given. There are numerous "see" references, plus "see also" references indicated by asterisks. Good typography, numerous illustrations, maps and plates contribute to the generally attractive format.

Volume 1 contains a special section on the flag, constitution and cabinet members of Indonesia, the Declaration of Human Rights, opening bars of national anthems, a table of heads of governments, and one of national holidays.-E.S.

\section{Periodicals}

Paris. Bibliothèque nationale. Catalogue des periodiques clandestins, 1939-1945. Paris, 1954. 282p. 880fr.

This is a catalog of clandestine serial publications distributed in Nazi-occupied countries. In three sections: 1) Periodicals distributed in France; 2) Periodicals distributed in other countries; 3) Supplement. As only those serials are listed of which original or photostatic copies are to be found in the Bibliotheque nationale, the listing for France is nearly complete, comprising 1015 titles, while the listing for other countries is partial, comprising only 71 titles. Bibliographical descriptions are full, including, whenever possible, publisher, place and date of publication of each issue. In the notes any additional available data, such as the names of editors, printers, contributors, etc., are given. There is a good detailed index.S.S.

Verzeichnis ausländischer Zeitschriften in Schweizerischen Bibliotheken. Répertoire des périodiques étrangers reçus par les bibliothèques suisses. 4.Aufl. Bern, Vereinigung Schweizerischer Bibliothekare, 1955. 620p.

1. ed. 1904; 2. ed. 1912; 3. ed. 1925.

P. xix-xl contain a list of institutions reporting with conditions of lending.

This union list includes some 34,300 titles, with indication of holdings, of foreign periodicals published since 1900 found in Swiss libraries. Arrangement is alphabetical by title even in the case of publications of societies and institutions, i.e., annual reports, bulletins, proceedings, etc. are entered directly under title instead of under the name of the sponsoring body as is done in American libraries. However, there is a geographic index which gives societies, institutions and government agencies under place name listing their publications and giving references to the entries in the main alphabet.

\section{RELIGION}

Barrow, John G. A Bibliography of Bibliographies in Religion. Ann Arbor, Edwards Bros., 1955. 489p. \$15. (For sale by the author, 716 Brown Bldg., Austin 1, Texas.)

A comprehensive compilation attempting "to bring together all separately published bibliographies in the field of religion." It does not include bibliographies appended to books and to articles in codices, or indexes of forbidden books.

The arrangement is by subject field with an author and subject index. Under each subject, titles are arranged chronologically by date of publication. Titles are annotated and location of copies in numerous American and European libraries is indicated. Unfortunately, subject headings do not stand out well in a lithoprinted work, and, as there are no running titles, it is necessary to work almost entirely from the table of contents.

\section{Bibliotheca catholica neerlandica im-} pressa, 1500-1727. Hagae Comitis, M. Nijhoff, 1954. 669p. fl. 40.

Intended as a "repertory of the spiritual literature" (i.e., "everything printed for the spiritual life") published in the Low Countries during the period indicated. Arrangement is chronological with a main-entry index. Information given includes place, publisher and date, but not pagination, and there are references from later to earlier editions of the same work. Compiled from bibliographies, library catalogs, etc. (of which there is a list with abbreviations), the fact that "none of the works listed was ever 
actually consulted" is partially compensated for by the inclusion of at least one source of reference for each entry.-E.S.

[Brunotte, Heinz] Evangelisches Kirchenlexikon; kirchlichtheologisches Handwörterbuch. Göttingen, Vandenhoeck und Ruprecht [1955- ] Lfg. 1-3 in 2 pts. DM. $4.80 / \mathrm{lfg}$.

An editorial group of German Protestant clergy and theological scholars has published the first sections of an encyclopedic dictionary, to be completed in three volumes (35 parts). It is intended as a modern supplement to older works of reference on Christian theology and church affairs, emphasizing recent literature, in particular the foreign literature unavailable in Germany for a considerable length of time. The editors expressly refer to Osterloh and Engelland, Biblisch-theologisches Handwöterbuch, 1950, for more thorough treatment of Biblical theology, and to the Evangelisches Soziallexikon, 1955, for greater detail in matters of Protestant social ethic. Entries include theological concepts, clerical terms, national and geographic areas with emphasis on their religious history, and biographies of persons associated with the field of religion. A stated aim is "to define concepts so as to enable readers to make their own judgments."

Approximately 16,000 entries are contemplated, with a series of long articles on major subjects as the main feature. Articles other than brief ones are signed and contain bibliographies.-E.B.

Williams Library, London. Dr. Williams's Library, London. Catalogue of Accessions, 1900-1950, Being a Catalogue of Books Published and Added to the Library during that Period. Ed. for the Trustees, by Doris M. Johnson. London, Dr. Williams's Trust, 1955. 776 , cxlv p. $£ 2.5$ s.

This library is particularly strong in theology, ecclesiastical history, history of religion, philosophy and related subjects, and also includes materials in history, sociology, and the history of language and literature.
It does not have fiction, science, technology or music.

The main part of the catalog, arranged alphabetically by author, is followed by a supplement which lists periodicals, publications of societies, connected series, etc. Only works published between 1900-1950 are included.

\section{Social Sciences}

Annuaire Européen, European Yearbook. Published under the auspices of the Council of Europe. The Hague, Nijhoff, 1955- . v.1- . 584p. G.28.50.

"Devoted to the scientific study of European international organizations, including their constitutions, their functions and their work," the first volume of this yearbook concentrates on eight principal organizations (e.g., Council of Europe, European Coal and Steel Community) with plans to include new and more technical institutions and to supplement present data in subsequent volumes. In three sections: Articles (historical and descriptive information); Documentary; and Bibliographical (abstracts of important books on European integration and a selected list of articles). Documents appear in both French and English, abstracts in English, and the bulk of the articles in French with English summaries. Indexed.-E.S.

Bernsdorf, Wilhelm and Bülow, Friedrich, eds. Wörterbuch der Soziologie, unter Mitarbeit zahlreicher Fachleute. Stuttgart, Enke, 1955. 640p. DM. 26.40.

A one-volume encyclopedic dictionary of sociological terms with signed contributions by 84 German specialists. Most articles contain brief bibliographies with American and English writings frequently cited. The work resembles Vierkandt's Handwöterbuch der Soziologie, 1931, but is arranged as a dictionary. Cross references are numerous, many referring from the English term. The editors state that the work is not intended as a major handbook for specialists but rather as a reference tool for students of social science and the practicing social worker. For reference purposes it should prove more satisfactory than a number of one-volume subject dictionaries of similar 
purpose now appearing in English. A supplementary volume on sociologists is planned.-E.B.

\section{Bibliography on the Communist Prob-} lem in the United States. New York, Fund for the Republic, 1955. 474p. \$5.

An annotated bibliography "primarily devoted to literature relating to Communism in the United States since . . 1919," this is one of two volumes on the subject published by the Fund for the Republic. The companion volume, Digest of the Public Record of Communism in the United States (New York, 1955), is a "collection of abstracts of decisions, laws, ordinances, hearings, reports and other public documents."

Arranged in two main indices, author and subject, the Bibliography is supplemented by five appendices. In general the closing date is 1952, but some later items are included. Hearings and other public documents are listed only in the companion volume.-E.S.

Hamburg. Welt-Wirtschafts-Archiv. Länderlexikon. Hamburg, Verlag Weltarchiv, 1955- . v.1- $\$ 38.25$ the set.

A new encyclopedia of the social and economic structure of the countries of Europe, exclusive of the Soviet Union, this first volume is to be followed by two more to encompass other major geographical regions. Arrangement is by country, with articles of substantial length, e.g., Great Britain, 150 pages. Topics covered include governmental structure, politics, social organization, geography, economics, finance, agriculture, trade, industry and education. Although there is some historical orientation, emphasis is on the present. Bibliographies seem adequate and current.-J.N.W.

Szladits, Charles. Bibliography on Foreign and Comparative Law; Books and Articles in English. N.Y., Oceana Pubs., 1955. 526p. \$15.

An extensive bibliography of some 14,000 books and periodical articles in English in the broad fields of foreign and comparative law not including Anglo-American legal systems. The arrangement is by a fairly detailed classification scheme with an index of authors and a geographic index. In many cases brief descriptive annotations are given for books, and some of what are considered the more important periodical articles are marked by asterisks. This should be an important work in the fields of political science and government as well as law.

\section{DICTIONARIES}

Belisle, Louis A. Dictionnaire géneral de la langue française au Canada. Québec, Belisle Editeur, 1955- . fasc. 1- . il. \$15.

To be published in about 33 fascicles of 64 pages each, the resultant volume to include some 2,000 pages, this is a general French dictionary, based on Littré, but particularly useful because it contains Canadianisms with their equivalents in literary French. A fleur-de-lis is used to indicate words and meanings peculiar to Canadian French. Special attention is given to $\mathrm{Ca}$ nadian flora and fauna, and terms of commerce and industry as well as technical terms.

Citations showing usage are drawn from French classical authors, from modern French and from the colloquial speech of the French in Canada.

\section{Corominas, Juan. Diccionario critico etimológico de la lengua castellana.} Berna, Ed. Francke, 1954- . v.l- . \$13. per vol.

A comprehensive etymological dictionary giving dates of origin of words with quotations showing usages and derivations. Covers the languages of both Spain and Spanish America and includes the ancient languages, such as pre-Roman Iberian and vulgar Arabic, as well as dialects and LatinAmerican influences.

Collison, Robert Lewis. Dictionaries of Foreign Languages; a Bibliographical Guide to the General and Technical Dictionaries of the Chief Foreign Languages, with Historical and Explana- 
tory Notes and References. New York, Hafner Pub. Co., 1955. 210p. \$4.

Prepared by an English librarian and based on the collection in an American university library, this bibliographical guide should be helpful to librarians, translators and others needing information about dictionaries. The selection is comprehensive, and historical and critical notes are given for the dictionaries of all the major languages of Europe, Africa and Asia. The larger chapters are divided into sections: general, etymological, specialist (synonyms, antonyms, etc.) dictionaries relating to special periods, slang and dialect, and bilingual (usually English, but with some important foreign-language dictionaries noted). An appendix lists technical dictionaries in various languages arranged by subject.

Snell, Bruno. Lexikon des frühgriechischen Epos. In Zusammenarbeit mit dem Thesaurus Linguae Graecae und mit Unterstützung der UNESCO und der Joachim-Jungius-Gesellschaft, Hamburg . . Göttingen, Vandenhoeck \& Ruprecht, 1955- . Lfg. 1- .

This new dictionary is the first part of the Thesaurus Linguae Graecae to be published. Although similar in its general intention to the Thesaurus Linguae Latinae, (Guide, M340) the Greek Thesaurus will contain when completed a series of dictionaries, each covering a different literary period. This one will list every word which occurs in the texts of the earliest Greek literary works up to but not including the works of Antimachos.-S.S.

\section{SCIENCE}

Sachet, Marie-Hèlène and Fosberg, F. Raymond. Island Bibliographies: $M i$ cronesian Botany; Land Environment and Ecology of Coral Atolls; Vegetation of Tropical Pacific Islands. Comp. under the auspices of the Pacific Science Board. [Washington] National Academy of Sciences-National Research Council, 1955. 577p. \$6.

In three separate sections (as suggested in the sub-titles), each section of this annotated bibliography is arranged by author and has its own subject index. Books, periodical articles, mimeographed material, and some unpublished items are included. Bibliographical information is given in abbreviated (and often unsatisfactory) form, but location of copies, primarily in Washington, D. C., libraries, is indicated. Indexing consists in grouping authors' names plus dates of publication under subject headings without indication of page number. There is a list of serial abbreviations and a separate addenda list for each section. -E.S.

\section{Applied Science}

De Vries, Louis. English-German Technical and Engineering Dictionary. 1st ed. N.Y., McGraw-Hill, 1954. 997p.

A companion volume to his German-English Technical and Engineering Dictionary (Guide, Suppl. IP5).

Lists more than 130,000 entries. Emphasis is on engineering terms but other technical and some few general terms are included.

Harvard University. Psycho-Acoustic Laboratory. Bibliography on Hearing. S. S. Stevens, Director; J. G. C. Loring, Compiler; Dorothy Cohen, Technical Editor. Cambridge, Mass., Harvard Univ. Pr., 1955. 599p. \$7.

An enlargement of A Bibliography in Audition, comp. by George A. Miller [and others]. 1950. 2v.

Covering the period 1938-1952, with a selection of materials before 1938, this edition contains over 10,000 titles, almost doubling those in the first edition and repeating all titles listed there. The large subject fields covered include: anatomical, biophysics, animal studies, speech and information, music, noise, neural activity, biochemistry and pharmacology, psychophysics, deafness, audiometry, and auditory theory.

The main arrangement is alphabetical by author with a subject index. Titles are usually given in the original language followed by an English translation in brackets. 


\section{Music}

\section{The Guide to Long-Playing Records.}

N.Y., Knopf, 1955. 3v. \$11.50.

Contents: v. 1, Orchestral music, by Irving Kolodin; v. 2, Vocal music, by Philip L. Miller; v. 3, Chamber and solo instrument music, by Harold C. Schonberg.

Three recognized experts present here an annotated list of the serious music available on long-playing records, which, by virtue of comprehensiveness and practicality, should be useful to a very large group. Listing is by composer, with subdivisions by musical form, and there are supplementary listings in volumes 2 and 3 of individual performers in collections, miscellanies, etc. Although no mention is made of a closing date, a number of early 1955 releases are included.

Relative merits of the several performances of a given work are clearly indicated, and although personal preferences are obvious (and properly so), the balance between objective and subjective criticism seems skillfully maintained. There are adequate indexes; the uninitiated, however, may be confused by the arrangement of abbreviations at the head of each title. Particularly noteworthy is the high literary standard of the text of the annotations.-J.N.W.

\section{LITERATURE}

Jonas, Klaus W. Fifty Years of Thomas Mann Studies, 1902-1951. Minneapolis, University of Minnesota Press, 1955. 217p. $\$ 5$.

A selective compilation of approximately 3,000 books, parts of books, pamphlets, and periodical and newspaper articles about Mann, covering the period 1902, the year in which articles on Buddenbrooks began to appear, through 1951, the year of publication of Der Erwahlte. However, important items of earlier or later dates are included, as well as Mann's self-critical and autobiographical writings. The systematic arrangement includes sections on bibliography, biography, themes, style, political, social and philosophical thought, research in progress, and on each of the author's novels, novelettes and short stories. Except in the case of newspaper citations, bibliographical information is complete and uniform.-K.L.

\section{BIOGRAPHY}

Who's Who in Librarianship, ed. by Thomas Landau. Cambridge, Bowes and Bowes, 1954. 268p. 50s.

The first of its kind for British librarians, Who's Who in Librarianship includes approximately 3,000 notices of the usual who's who nature, although comparison with other sources of information suggests a rather high percentage of omissions. "Special interests" are noted in most of the sketches, and these have been further used to form a number of supplementary classified lists.

Who's Who in Library Service. 3d. ed., Dorothy Ethlyn Cole, ed. N.Y., The Grolier Society, 1955. 546p. \$6.

This new edition of Who's Who in Library Service lists some 11,000 U. S. and Canadian librarians, with personal and professional data which seem pertinent, accurate and, for the most part, current. Information is based on questionnaires sent to graduates of approved library schools and members of the several national library associations; apparently, those librarians failing to reply were excluded, regardless of other considerations.-J.N.W.

Who's Who in World Aviation. Washington, D.C., American Aviation Publications, 1955- . v. 1- . \$10.

Includes some 2400 names covering officials of aircraft companies and airlines; officers of the air services of all countries; distinguished members of pioneer pilot organizations; government officials and legislators with significant interest in aviation, etc.

\section{Atrases}

Atlas mira. [A. N. Baranov, V. N. Lysiuk, S. I. Shurev and others, editors] Moscow, 1954. [13]p. 283p. of colored maps. $51 \mathrm{~cm} . \$ 55$.

A world atlas, in Russian, prepared under 
the Chief Administration of Geodesy and Cartography of the Ministry of Internal Affairs, by order of the Council of Ministers of the U.S.S.R.

Maps are primarily physical and political; unlike the Bol'shoi sovetskii atlas mira (Guide U169) there are no economic or historical maps. Considerable emphasis is given to communication routes. Seventy-five maps (or approximately $25 \%$ ) are of the U.S.S.R. and its subdivisions, and 105 are devoted to Western Europe. Remaining sections include Asia (52), Africa (17), North America (91), South America (14), and Australia, the oceans and polar regions (17). The bulk of the work was completed in 1953. The index, to be published separately, is not yet available. To facilitate reference to the key to symbols a duplicate unbound page on firm paper is provided.

The cartographic methods employed appear to be of superior quality, and format is comparable with the best atlases published in Europe.-E.B.

Svenska sällskapet för antropologi och geografi, Stockholm. Atlas över Sverige. Stockholm, Generalstabens litografiska anstalts forlag, 1953- . \$112 complete.

A new and valuable regional atlas of Sweden, which, when complete, will contain 150 folio-size colored maps together with descriptive texts and will afford a thorough treatment of all aspects of Swedish geography. The fourteen sections will include material on geophysics and geology, meteorology and hydrography, pasturage and animal husbandry, population, agriculture, forestry, industry, communications, trade, economic conditions, social conditions, cultural development, political geography and history. There are extensive English summaries in each folio section, and all maps and tables have parallel English headings. Scheduled to be completed in about three years, the atlas will contain seventy-five fascicles (kartblad) of which fifteen have been issued.K.L.

\section{History}

Diccionario historico argentino, publicado bajo la dirección de Ricardo
Piccirilli, Francisco L. Romay [y] Leoncio Gianello. Buenos Aires, Ediciones Historicas Argentinas [19531954] 6v. $\$ 70$.

This alphabetical dictionary consists, in general, of brief articles on persons, places and institutions connected with the history of Argentina. Some longer, survey-type articles on broader subjects are also included. As the chief emphasis is on biography, numerous sketches of eminent artists, scientists and educators, in addition to those of historical figures, are included. Unusual but useful, especially to librarians, is the inclusion of articles on the history of the country's major periodicals and newspapers.

Although prepared by Argentine scholars, the articles are not signed and the bibliographies are brief and scattered. Furthermore the work has not been indexed and cross references have generally been omitted. Thus, unfortunately, the wealth of information accumulated here is not readily accessible.-S.S.

Historical Abstracts: a quarterly of $a b$ stracts of historical articles appearing currently in periodicals the world over . . . Eric H. Boehm, Editor. v.l, no.l- March, 1955- . Vienna, Historisches Seminar, 1955- quarterly. $\$ 15$ to individuals and to institutions with an annual book fund of less than $\$ 10,000 ; \$ 25$ to institutions with an annual book fund of more than $\$ 10$,000.

The first two issues of this new abstract journal in the historical field contain almost 1700 abstracts from more than 400 periodicals, with the expectation that coverage will be extended to more than 600 periodicals by the end of volume two. It is intended to include articles on "political, diplomatic, economic, social, cultural and intellectual history appearing on the period 1775-1945 in the periodical literature (including year books) the world over."

Each issue will also include a brief news section, installments of a World List of Historical Periodicals, a list of the periodicals abstracted; and subject and author indexes. 